\title{
Jokowi, Masalah Ketidalkmerataan dan Demokrasi di Indonesia
}

\section{Edward Aspinall}

Guru Besar pada Jurusan Ilmu Politik dan Perubahan Sosial, Universitas Nasional Australia

\section{Abstract}

The new president, Joko Widodo, won elections in 2014 by mobilizing support from the poor, presenting himself as someone who was uniquely able to understand the needs of the poor and offering them wider health care, education, and various services other social. One of the earliest policies was the distribution of aid programs to poor families which would eventually reach one third of Indonesia's population, making this program, according to The Economist magazine, "the largest of similar programs around the world.

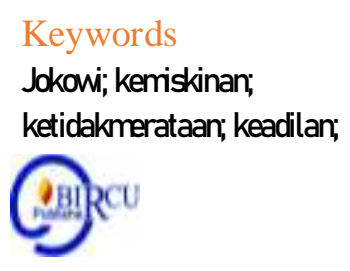

\section{Pendahuluan}

Di tahun-tahun menjelang jatuhnya Presiden Suharto pada tahun 1998, ada debat publik yang berkembang di sejumlah media mengenai meningkatnya apa yang disebut sebagai "kesenjangan sosial". Upaya liberalisasi ekonomi pada tahun 1980-an telah diikuti dengan pertumbuhan pesat dari sejumlah industri manufaktur dan keuangan, dan tanda-tanda kekayaan kelompok ekonomi menengah semakin terlihat jelas di berbagai kota Indonesia. Masyarakat juga semakin menyadari tumbuhnya kelompok pedagang super kaya, yang biasanya merupakan anak atau anggota keluarga dari pejabat tinggi pemerintah. Seruanseruan untuk keadilan sosial mendorong perasaan tidak puas terhadap rezim Suharto, yang meledak dengan brutal di beberapa jalanan kota Jakarta dan kota-kota besar lainnya lewat berbagai demonstrasi dan kerusuhan yang mendahului dan menyertai perubahan rezim pada tahun 1998. Banyak orang Indonesia yang berharap bahwa era reformasi tidak hanya akan membawa politik yang lebih terbuka dan demokratis, tetapi juga keadilan sosial yang lebih besar.

Harapan-harapan tersebut belum terwujudkan. Semenjak Indonesia memulai transisi demokrasi pada tahun 1998, ketidakmerataan kekayaan telah meningkat secara signifikan. Kesenjangan sosial yang semakin mendalam paling sering dihubungkan, dibandingkan faktor lainnya, dengan kenaikan kekayaan secara dramatis dari mereka yang sangat kaya, dan juga pendapatan masyarakat miskin yang tidak mengalami peningkatan. Akan tetapi, upaya-upaya untuk menghapus ketidakmerataan tidak mendapat perhatian utama di dalam kehidupan politik Indonesia. Terlepas dari ketegangan-ketegangan egalitarianisme yang mendalam di budaya politik Indonesia, dan terlepas dari banyaknya gerakan sosial dengan basis masyarakat miskin, pembagian masyarakat berdasarkan kelas sosial tidak menghasilkan bentuk sistem partai politik dan tidak ada usulan program redistribusi yang terstruktur, terlebih lagi yang diprakarsai oleh pemerintah. Justru, yang mendominasi politik pemerintah adalah pemain-pemain politik kaya, dan pengambilan suara rakyat diintegrasi secara politik mula-mula melalui politik uang, yaitu para politisi menawarkan berbagai keuntungan tertentu bagi para pemilih, ketimbang redistribusi sosial bagi masyarakat luas. Akan tetapi, politik redistribusi menjadi semakin mencolok secara politik, seperti yang 
dibuktikan dengan meningkatnya jumlah pemilih yang tertarik pada politisi yang mengupayakan kebijakan-kebijakan kesehatan, pendidikan, dan kesejahteraan sosial lainnya.

\section{Kajian Pustaka}

\section{Ketidakmerataan di Indonesia}

Menurut catatan sejarah, ketidakmerataan di Indonesia berada pada tingkat yang lebih rendah dibandingkan di negara-negara tetangga utamanya di Asia Tenggara. Akan tetapi, statistik-statistik pemerintah mengisyaratkan bahwa ketidakmerataan mulai memburuk sejak satu dekade yang lalu, dan dengan laju yang semakin cepat. Koefisien Gini, yang mengukur ketidakmerataan pendapatan, meningkat dari 0,32 pada tahun 2002 menjadi 0,41 pada tahun 2013, meskipun sebagian besar pengamat percaya bahwa angka-angka ini tidak menggambarkan dengan tepat kondisi ketidakmerataan yang sebenarnya di Indonesia. Secara khusus, angka-angka tersebut tidak berhasil menggambarkan konsentrasi kekayaan yang luar biasa pada kelompok ekonomi paling atas.

Para ekonom dan analis lainnya telah memperdebatkan penyebab dari ketidakmerataan yang semakin mendalam ini. Salah satu faktor adalah pendapatan masyarakat miskin di Indonesia yang tidak mengalami peningkatan atau meningkat dengan laju yang relatif lambat. Oleh karena itu, satu hasil penelitian baru-baru ini telah menunjukkan bahwa mereka yang tergolong di dalam kelompok miskin dan hampir miskin, dibandingkan kelompok tingkat ekonomi rata-rata, hanya memperoleh keuntungan terbatas dari pertumbuhan ekonomi akhir-akhir ini. Meskipun jumlah resmi dari mereka yang digolongkan ke dalam kelompok miskin berkurang dari 18,4 persen dari total populasi pada tahun 2002 menjadi 11,2 persen dari total populasi pada tahun 2013, jumlah dari mereka yang tergolong ke dalam kelompok miskin bersama-sama dengan kelompok 'hampir miskin' yang berjumlah lebih besar, masih menyusun kurang lebih setengah dari populasi. Berdasarkan Bank Dunia, pada tahun 2011, 43 persen dari total populasi Indonesia hidup dengan kurang dari 2 dolar Amerika Serikat per hari.

Di lain sisi, meskipun jumlah kelompok ekonomi menengah di Indonesia telah mengalami peningkatan nyata secara signifikan, pada kelompok ekonomi terataslah terjadi aksi yang paling dramatis. Selama kurang lebih satu dekade terakhir, telah ada suatu konsentrasi kekayaan yang luar biasa di antara orang-orang ultra kaya Indonesia. Ilmuwan politik Amerika Jeffrey Winters menghitung pada tahun 2011 bahwa 43 ribu orang-orang terkaya di Indonesia, yang mewakili kurang dari satu persen dari satu persen populasi Indonesia, memiliki total kekayaan yang setara dengan 25 persen GDP Indonesia, sementara 40 orang terkaya memiliki total kekayaan yang setara dengan kurang lebih 10 persen GDP. 2Pada tahun 2012, jumlah miliarder Indonesia melampaui Jepang, dan Indonesia juga memiliki jumlah miliarder per kapita yang lebih besar dibanding Tiongkok dan India. 3 Pada awal tahun 2014, Wealthinsight, suatu institusi yang menyediakan data tentang 'individu-individu bernilai tinggi dan ultra tinggi secara global', menyatakan bahwa Indonesia memiliki laju pertambahan jutawan tercepat di dunia, memperkirakan suatu kenaikan dari 37 ribu jutawan pada tahun 2013 menjadi lebih dari 45 ribu jutawan pada tahun 2014, atau naik sebesar 22,6 persen. 4 Setahun sebelumnya, satu kelompok yang serupa, Wealth-X, menghitung ada 785 individu 'bernilai ultra tinggi' (orang-orang yang bernilai setidaknya 30 juta dolar Amerika Serikat per individu) di Indonesia, dengan total kekayaan 130 miliar dolar Amerika, naik sebesar hampir 17 persen dibanding tahun sebelumnya. Credit Suisse, juga tidak mau kalah, memperkirakan suatu kenaikan jumlah jutawan Indonesia dari 98 ribu orang pada tahun 2014 menjadi 161 ribu orang pada tahun 2019, naik sebesar 64 persen. Dan perkiraan-perkiraan tersebut mungkin sekali ditetapkan 
tanpa memperhitungkan orang-orang kaya Indonesia yang tinggal di luar negeri: pada tahun 2006, majalah Tempo melaporkan bahwa sekitar sepertiga dari para jutawan yang hidup di Singapura merupakan warga negara Indonesia, kebanyakan dari mereka pindah ke Singapura setelah krisis ekonomi pada tahun 1997-1998.

There has been a massive concentration of wealth among Indonesia's ultra rich over the last decade.

Peningkatan konsentrasi kekayaan ini merupakan bagian dari tren global, tapi satu faktor yang mempercepatnya di Indonesia adalah boom komoditas yang terjadi selama tahun 2000-an, ketika harga dan produksi dari beberapa komoditas utama seperti batu bara dan minyak sawit naik dengan tajam. Fakta bahwa keuntungan dari boom ini sangat terkonsentrasi di kelompok ekonomi atas dari masyarakat Indonesia, ketimbang membawa keuntungan bagi masyarakat miskin, menunjukkan peran penting faktor-faktor politik dalam membentuk struktur dan mempertahankan ketidakmerataan di Indonesia. Pada khususnya, penerima utama dari keuntungan boom komoditas adalah para pengusaha dengan koneksi politik yang memungkinkan mereka memperoleh izin dan konsesi yang diperlukan guna membuka dan mengoperasikan tambang-tambang dan perkebunan. Termasuk di dalamnya adalah para pengusaha utama di Jakarta, juga barisan pedagang kaya baru, para birokrat dan politisi di daerah-daerah yang mampu memanipulasi kelonggaran yang diberikan kepada pemerintah lokal atas nama sejumlah aturan desentralisasi untuk kepentingan mereka sendiri. Walaupun orang-orang Indonesia dengan kekayaan yang luar biasa tetap terkonsentrasi di Jakarta dan Singapura, boom kekayaan besar juga terjadi di daerah-daerah, dan bukanlah hal yang mustahil untuk menemukan berbagai bukti dari kekayaan yang luar biasa, misalnya banyaknya rumah megah seperti istana dan pesawat jet pribadi, bahkan di daerah-daerah yang relatif terpencil.

Hubungan yang erat di antara kekayaan pribadi dengan kekuasaan politik seperti yang ditunjukkan oleh boom komoditas pada kenyataannya telah menjadi satu ciri ekonomipolitik Indonesia, dengan sebagian besar dari orang-orang terkaya Indonesia berasal baik dari keluarga-keluarga dengan pengaruh politik, atau dari keluarga-keluarga yang mampu memanfaatkan pelindung-pelindung politik dan mitra-mitra di pemerintahan selama dan setelah era Suharto. Karena itu, politik dari oligarki Indonesia telah menjadi kekhawatiran utama dari banyak analisis penting tentang politik Indonesia di era pasca-Suharto. 7 Dalil utama dari teori tentang oligarki ini adalah bahwa sebagai konsekuensi dari krisis ekonomi dan politik pada akhir 1990-an, para pemegang kekuasaan menyandera institusi-institusi terpenting dari demokrasi Indonesia, seperti partai dan parlemen dan juga mendominasi masyarakat sipil melalui kontrol mereka atas institusi-institusi penting tersebut lewat media massa. Menurut teori ini, persaingan atas kekuasaan politik pada dasarnya merupakan persaingan di antara para pemegang kekuasaan pemerintahan yang mengejar akses terhadap sumber-sumber ekonomi yang dapat diberikan oleh kekuasaan negara. Persaingan seperti itu dapat menjadi kejam- dan seperti yang diungkapkan oleh Jeffrey Winters, Indonesia merupakan suatu "oligarki liar".

Grasberg mine open pit. The largest gold mine and the third largest copper mine in the world. It is located in the province of Papua in Indonesia.

\section{Pembahasan}

\section{Ketidakmerataan, Politik, dan Gagasan}

Ketidakmerataan sosial yang ekstrim tentu saja tidak hanya ada di Indonesia atau Asia Tenggara. Justru, seperti yang telah dijelaskan oleh hasil karya terbaru Thomas Piketty yang dikenal luas, ketidakmerataan sosial merupakan ciri mendalam dari negara-negara kapitalis 
maju, dan sesuatu yang telah menjadi semakin populer selama beberapa dekade terakhir. Untuk mempertahankan ketidakmerataan dibutuhkan suatu konteks ide pendukung. Di kebanyakan masyarakat dukungan ini dicapai melalui dua unsur yang muncul dalam berbagai campuran dan bentuk. Yang pertama adalah suatu ideologi yang membenarkan ketidakmerataan, sebagai contoh dengan menyatakan bahwa hirarki sosial disucikan oleh Tuhan atau kekuatan supernatural lainnya, atau dengan menyatakan bahwa orang-orang miskin bertanggung jawab secara pribadi atau kolektif atas kondisi mereka sendiri dan bahwa orang-orang kaya berhak atas kekayaan mereka karena bakat, kerja keras, prinsip keturunan, tradisi, atau faktor-faktor lainnya. Kedua, serangkaian ide mencoba untuk memperlemah dampak dari ketidakmerataan, termasuk di dalamnya mendorong campur tangan negara atas ekonomi dan kehidupan sosial untuk redistribusi kekayaan, atau setidaknya, memperbaiki sejumlah efek terburuk dari ketidakmerataan. Ide-ide tersebut juga ada di dalam semua masyarakat, meskipun ide-ide tersebut secara khusus telah diasosiasikan sebagai upaya dalam membangun negara kesejahteraan selama abad terakhir. Meskipun campur tangan negara kesejahteraan pada saat tertentu telah mengurangi ketidakmerataan secara signifikan di sejumlah negara, akan tetapi mereka tidak pernah benar-benar berniat untuk meniadakannya.

Di Indonesia, struktur ide apakah yang menyokong ketidakmerataan? Satu titik mula untuk pengamatan ini adalah survei berskala nasional yang diadakan pada Juni 2014 oleh dua lembaga survei: Lembaga Survei Indonesia dan Indikator Politik Indonesia. 8 Kedua survei tersebut mengungkap kekhawatiran sosial yang mendalam mengenai ketidakmerataan. Meskipun para responden (seperti warga negara dari negara-negara lain) menganggap rendah skala ketidakmerataan yang sebenarnya di Indonesia, 51,6 persen responden melihat Indonesia pada saat ini sebagai sesuatu yang tidak merata, sementara 40,1 persen responden melihat Indonesia sangat tidak merata (hanya 6,6 persen responden yang mengatakan bahwa Indonesia sepertinya merata dan 0,5 persen responden, sangat merata). Hampir seperempat, 23,3 persen, dari responden mengatakan bahwa kesenjangan pendapatan tidak dapat diterima dengan alasan apapun. Sementara lainnya, yaitu-66,3 persen,- mengatakan bahwa kesenjangan pendapatan dapat diterima dengan kondisi tertentu, tapi yang menarik adalah bahwa dari responden-responden ini, hanya 18 persen yang memilih pembenaran atas ketidakmerataan dengan merujuk pada legitimasi sosial:" "mereka yang kaya adalah kaya sebagai hasil dari kerja keras, sementara mereka yang miskin adalah miskin karena mereka malas". Kebanyakan dari mereka yang mengatakan bahwa ketidakmerataan dapat diterima dengan kondisi tertentu mensyaratkan bahwa tindakan negara diperlukan untuk memperbaiki kondisi masyarakat miskin dan dengan demikian membuat ketidakmerataan dapat diterima: jika barang-barang kebutuhan pokok terjangkau oleh semua orang (23,6 persen), jika kemiskinan berkurang (17,5 persen), jika negara secara keseluruhan mengalami kemajuan (17,5 persen) dan jika persaingan untuk memperoleh kekayaan dilakukan secara adil (16,3 persen).

Hasil survei-survei ini menunjuk pada suatu etos egalitarianisme yang kuat di masyarakat Indonesia, dan ketidaksukaan atas ketidakmerataan sosial yang kuat. Berakar pada tema-tema ekonomi nasionalis dan sosialis dari perjuangan anti-penjajahan, diskusi politik publik secara lisan tetap statis dan berorientasi pada kesejahteraan. Istilah-istilah seperti 'liberalisme' dan bahkan 'kapitalisme' adalah suatu pantangan, bahkan di antara kelompok politik yang telah mapan, dan semua partai politik utama sering sekali menyatakan bahwa negara harus terlibat secara ekonomi untuk memperbaiki nasib masyarakat miskin. Akan tetapi, meskipun tersebar luas, sentimen seperti itu tidak terfokus. Komitmen retorik yang luas terhadap konsep kesejahteraan dan pemerataan jarang disertai dengan, sebagai contoh, pembicaraan mengenai peningkatan beban pajak atas masyarakat kaya Indonesia guna memungkinkan redistribusi secara serius. 


\section{Hambatan dan Prospek}

Sebagian besar penjelasan tentang mengapa dukungan luas yang populer atas pemerataan gagal menjelma menjadi upaya-upaya lebih kuat untuk mengendalikan ketidakmerataan terletak pada hakikat dari politik pemegang kekuasaan. Satu faktor adalah ketiadaan partai politik yang secara struktur mewakili masyarakat miskin. Tidak ada, sebagai contoh, partai demokratis yang memiliki hubungan dengan serikat-serikat buruh. Ini tidaklah berarti bahwa tidak ada gerakan-gerakan sosial atau mobilisasi di antara masyarakat miskin; sebaliknya, gerakan-gerakan tersebut dapat ditemukan di mana-mana dan di sejumlah sektor (seperti organisasi buruh) telah menjadi semakin tegas selama dekade terakhir. Tetapi gerakan-gerakan sosial ini terpecah-belah, berfokus pada perubahan kebijakan secara sedikit demi sedikit, dan pada akhirnya hanya berhasil membuat perjanjian guna persekutuan politik di saat pemilihan umum. Terkait dengan itu, hambatan lainnya adalah pengaruh kuat politik uang dalam menghubungkan warga negara dengan wakil politik mereka: meskipun para politisi mendekati warga negara dengan menggunakan bahasa umum mengenai keadilan dan kemerataan sosial, apa yang mereka tawarkan biasanya merupakan keuntungan yang praktis ditujukan hanya untuk para pendukungnya: proyek pembangunan di satu desa tertentu, program bantuan sosial yang disalurkan melalui organisasi keagamaan pendukung, hadiahhadiah pribadi atau pembagian uang pada saat pemilihan, dan lain-lain. Politik uang seperti ini memang menunjukkan satu bentuk redistribusi secara kasar dan cepat, tetapi hanya pada tingkat yang rendah dan hanya pada situasi tertentu. Ini juga merupakan satu cara dari praktek politik yang mengutamakan pemain-pemain kaya dan dengan demikian membantu, dalam jangka waktu panjang, untuk mempertahankan ketidakmerataan ketimbang menguranginya.

Dan meskipun demikian, terlepas dari semua hambatan seperti itu, tanda pertama dari suatu paradigma baru mengenai kesejahteraan sosial dan mungkin, redistribusi di dalam politik Indonesia telah menjadi kenyataan. Selama dekade terakhir, khususnya didorong oleh penerapan pemilihan kepala daerah secara langsung, banyak pemerintah daerah yang telah mulai memperkenalkan kebijakan-kebijakan kesejahteraan sosial yang baru, khususnya menyangkut masalah kesehatan. Satu rencana asuransi kesehatan umum yang baru telah diberlakukan pada tingkat nasional.

\section{Kesimpulan}

Presiden Joko Widodo memenangkan pemilihan pada tahun 2014 dengan memobilisasi dukungan dari masyarakat miskin, menampilkan dirinya sebagai seorang yang secara unik mampu memahami kebutuhan-kebutuhan masyarakat miskin dan menawarkan kepada mereka perawatan kesehatan dengan lingkup yang lebih luas, pendidikan, dan berbagai layanan sosial lainnya.

Salah satu dari kebijakannya yang paling awal adalah program pembagian dana bantuan terhadap keluarga-keluarga miskin yang pada akhirnya akan menjangkau sepertiga dari populasi Indonesia, menjadikan program ini, menurut majalah The Economist, "yang terbesar di antara program-program serupa di seluruh dunia."

Dengan singkat, naluri egalitarian masyarakat Indonesia perlahan-lahan diikuti dengan kebijakan-kebijakan nyata. Meskipun tantangan nyata dan mendasar atas ketidakmerataan kekayaan jelas tidak akan terjadi, setidaknya kita tengah menyaksikan langkah-langkah pertama yang ditujukan untuk mengatasi masalah tersebut. 


\section{Daftar Pustaka}

Elwell, Craig K. (2013) 'Economic Recovery: Sustaining US Economic Growth in a PostCrisis Economy', Congressional Research Service, April 18 (https://www.fas.org/sgp/crs/misc/R41332.pdf; accessed on 14 May 2015)

Bremmer, Ian (2014). 'The Tragic Decline of American Foreign Policy' The National Interest, April 16 (http://nationalinterest.org/feature/the-tragic-decline-americanforeign-policy-10264; accessed on 14 May 2015)

Solis, Mariya. (2015) The Geo-Political Importance of the Trans-Pacific Partnership - At Stake a Liberal Economic Order, March 13 (http://www.brookings.edu/blogs/orderfrom-chaos/posts/2015/03/13-geopolitical-importance-transpacific-partnership, accessed on 14 May 2015)

One Belt, One Road, Caixin Online, 12 October 2014 (http://english.caixin.com/2014-1210/100761304.html); The AIIB: China's Rising Influence in Asian Development Finance, ANZ Research, 26 March 2015.

World Shipping Council, Top 50 World Container Port (http://www.worldshipping.org/about-the-industry/global-trade/top-50-world-containerports; accessed on 14 May 2015)

UNCTAD, Review of Maritime Transport 2013, pp. 58-59. and 'Top 100 Existing Fleet in February 2015', (http://www.alphaliner.com/top100/)

China's Foreign Ports: The New Masters and Commanders, The Economist, July 8, 2013 (http://www.economist.com/news/international/21579039-chinas-growing-empireportsabroad-mainly-about-trade-not-aggression-new-masters; accessed on 14 May 2015)

China Pledges US\$40 billion for Silk Road Plan, Outlook, November 8, 2014 (http://www.outlookindia.com/news/article/China-Pledges-USD-40-Bn-for-Silk-RoadPlan/867047)

Where will the funds come from for the Belt and Road Strategy?, China Merchant Securities (HK) Co Ltd, Macro Report, January 16, 2015.

One Belt, One Road, Caixin Online, 12 October 2014 (http://english.caixin.com/2014-1210/100761304.html); The AIIB: China's Rising Influence in Asian Development Finance, ANZ Research, 26 March 2015.

Kim, Sangkyom; Park, Innwon and Park, Soonchan (2013), 'A Free Trade Area of the Asia Pacific (FTAAP): Is it Desirable?', Journal of East Asian Economic Integration, Vol. 17, No. 1, pp. 3-25. (http://www10.iadb.org/intal/intalcdi/PE/2013/11844.pdf)

Mark E. Manyin et al, Pivot to the Pacific? The Obama Administration's "Rebalancing" Toward Asia, Congressional Research Service (http://www.fas.org/sgp/crs/natsec/R42448.pdf); Sanchita Basu Das, The Trans-Pacific Partnership as a Tool to Contain China: Myth or Reality? ISEAS Perspective, 17 May 2013 (http://www.iseas.edu.sg/documents/publication/ISEAS_perspective_2013_31the-tpp-as-a-tool-to-contain-china-myth-or-reality.pdf)

'Chinese dream', Xi Jinping outlines vision for 'Asia-Pacific dream' at Apec meet, South $\begin{array}{lllll}\text { China } & \text { Morning } & \text { Post, } & \text { China, } & 10\end{array}$ (http://www.scmp.com/news/china/article/1635715/after-chinese-dream-xi-jinpingoffers-china-driven-asia-pacific-dream?page=all)

China Sees Itself at Center of New Asian Order, The Wall Street Journal, 9 November 2014 http://www.wsj.com/articles/chinas-new-trade-routes-center-it-on-geopolitical-map1415559290

World Economic Forum, The Global Competitiveness Report 2014-2015 (http://www3.weforum.org/docs/WEF_GlobalCompetitivenessReport_2014-15.pdf) 